\title{
SYMPATIE A PROSTOROVOST VÁŠNÍ V HUMOVĚ POJEDNÁNÍ
}

\section{Hynek Janoušek}

V této stati se budeme věnovat teorii sympatie, kterou rozpracoval David Hume v druhé knize svého Pojednání o lidské přrirozenosti. ${ }^{1}$ Humova teorie je výrazným příspěvkem k teoriím vcítění a koncepcím, jež se zabývají přístupem k mysli druhých lidí. Do její povahy se promítá Humovo nové pojetí funkce rozumu v lidské přirozenosti a důraz, který Hume kladl na sociální rozměr konstituce personálního já. Z tohoto důvodu může být následující text přínosný nejen pro čtenáře zajímajícího se o Humovu filosofii či o dějiny teorie vcítění, ale i pro ty, kteří se o tuto problematiku zajímají v rámci současných filosofických diskusí. Výklad Humovy teorie zde však nebude naším jediným cílem. Pokusíme se také upozornit na některé její zajímavé aspekty, které odborná humovská literatura přehlíží.

Jelikož termín ,sympatie“ se dnes ani v angličtině obvykle nepoužívá ve významu, který měl v 18. století, je třeba jej nejprve stručně objasnit a dále nastínit, o co nám $\mathrm{v}$ této stati půjde. Hume a autoři tohoto období používali termín sympatie (sympathy) zejména ve třech spřízněných významech. Základním významem je význam cítění s druhým (fellow-feeling) ve smyslu pocit'ování toho, co druhý pocit’uje, tj. pocit'ování jeho emocí. Velmi blízké tomuto významu je pojetí sympatie jako souznění emocí, jež je rovněž základní lidskou potřebou. V sympatii se za jistých okolností štěstí druhého stává naším štěstím a neštěstí druhého naším neštěstím. A naopak naše štěstí se stává štěstím druhých osob a naše neštěstí je rmoutí. Jelikož toto sladění stupňuje naše štěstí a ulevuje našemu neštěstí, zatímco nesoulad štěstí utlumuje a neštěstí prohlubuje, byla realizace sympatie považována některými autory za nezbytnou podmínku

1 D. Hume, A Treatise of Human Nature, vyd. L. A. Selby-Bigge - P. H. Nidditch, Oxford 2009. V textu je dílo uváděno pod českým názvem Pojednání o lidské přrozenosti, v odkazech je zkracováno jako Pojednání, s uvedením pořadí knihy, čísla stránek jsou předeslána zkratkou SB (Selby-Bigge). Citace první knihy jsou převzaty z českého vydání: D. Hume, Pojednání o lidském rozumu, přel. H. Janoušek, Praha 2015, které obsahuje číslování SB na pravém okraji Humova textu. 
lidského štěstí vůbec. ${ }^{2}$ Konečně třetím významem je sympatie ve smyslu soucitu (compassion). Tento význam je zúžením předcházejícího významu na oblast utrpení a jednání, které takové sou-cítění může motivovat. ${ }^{3}$

Zaměříme se zde na popis principu sympatie v druhé knize Pojednání o lidské prirozenosti, v níž sympatie vystupuje zejména jako pasivní psychologický princip prožívání pocitů druhých. Důvod tohoto omezení na druhou knihu je praktický. Ve třetí knize Pojednání je totiž sympatie vyložena také jako zdroj morálních citů prožívaných ze specifického, obecného hlediska. Výklad sympatie v kontextu Humovy morálky a otázka její př́ípadné aktivní povahy oproti pasivnějšímu pojetí druhé knihy však výrazně přesahuje možný rozsah tohoto textu. ${ }^{4}$

Výklad vlastního obsahu Humovy teorie pak bude mít dvě části. Nejprve se pokusíme krátce představit Humovu koncepci sympatie v druhé knize Pojednání a objasnit, jaký smysl má Humovo tvrzení, že v sympatii se mění ideje vášní v imprese. Přitom probereme dva aspekty Humovy koncepce, které bývají v sekundární literatuře přehlíženy. Budeme se ptát, jednak jak se liší význam termínů ,živost“ a „„̌̌ivé pojetî“v druhé knize Pojednání od významu těchto termínů v knize první, jednak jak chápat Humovu teorii emocionální „nákazy“ emocemi, tj. Humovo tvrzení, že emoce na nás bez našeho přispění přecházejí a stávají se našimi vlastními.

V druhé, spekulativnější části stati se budeme zabývat tím, jak se to má se vztažením vášní k prostoru. Jelikož vášně jsou podle Huma neprostorové percepce, nelze pojetí prožitků druhého chápat jako příčinný úsudek z tělesného vnějšku na skryté duševní nitro. Hume se však jen stěží mohl domnívat, že jsme v rámci běžné, každodenní komunikace osob srozuměni s tím, že usuzujeme na vášně osob, které se nikde nenacházejí. Kde se tedy podle naší každodenní víry nacházejí? Na základě analýzy textu Pojednání o lidské přirozenosti budeme hájit tvrzení, že řešení tohoto problému u Huma přirozeně plyne z jeho teorie ,ztělesnění“

2 Tento význam sympatie zdůraznil A. Smith ve své Theory of Moral Sentiments, London 1761, str. 1-29.

3 Srv. též H. Home, Elements of Criticism, I, Indianapolis 2005, kap. 15, str. 308. Jelikož v některých spojeních zní přirozeněji termín „,vcítění“, budeme ho v následující diskusi občas užívat jako synonymum termínu ,sympatie“, ačkoli oproti tomuto termínu konotuje aktivní snahu pochopit, co druhý prožívá. Pro mírně odlišnou klasifikaci významu ,sympatie“ viz L. Turco, Sympathy and Moral Sense: 1725-1740, in: British Journal for the History of Philosophy, 7, 1999, str. 79-101.

$4 \mathrm{~K}$ tomuto aspektu viz např. P. S. Árdal, Passion and Value in Hume's Treatise, Edinburgh 1966, str. 41-79. 
neprostorových percepcí obsažené v první knize Pojednání. Podporu pro to, abychom přenesli řešení z oblasti smyslů do oblasti vášní, nám poskytuje zjevná obecnost, s níž Hume v první knize Pojednání řeší problematiku vztahu neprostorově a prostorově uspořádaných percepcí mysli, a také fakt, že opak by byl zjevně absurdní.

Je třeba dodat, že volba tématu prostorovosti vášní u Huma je v druhé části naší práce motivována tím, že přestože o Humově teorii sympatie v Pojednání o lidské přirozenosti bylo napsáno velké množství literatury, otázku vztažení neprostorových vášní k prostorovému tělu si podle všeho dosud nikdo vážně nepoložil..$^{5}$ Jedná se o poměrně překvapivé zjištění, nebot' důraz na tělesnou povahu osob patří od publikování známé knihy Anette Baierové A Progress of Sentiments mezi standardní prvek humovských bádání.

\section{Humovo pojetí sympatie v druhé knize Pojednání o lidské přirozenosti}

Podívejme se však nejprve blíže na Humovo pojetí sympatie. Prožívání emocí druhého se podle obvyklého výkladu Huma, který, jak uvidíme, má oporu i v druhé a třetí knize Pojednání, zakládá v asociativním, zvykovém příčinném vyvození, díky němuž se nám např. tělesné výrazy tváře či tělesný postoj ukazují jako účinky mentálních př́íčin. Hume se $\mathrm{k}$ této příčinné povaze své teorie hlásí např. v následující pasáži:

„Když vidím účinky vášně v hlase a gestech nějaké osoby, má mysl bezprostř̌edně přechází z těchto účinků $\mathrm{k}$ jejich př́činám... Mysli se neodhaluje žádná vášeň druhého bezprostředně. Pocit'ujeme jen její

5 K tomuto názoru jsem dospěl po prostudování řady článků a několika knih, jež poskytují základní vhled do problematiky. Mezi nimi např. A. Waldow, David Hume and the Problem of Other Minds, New York 2011; A. E. Pitson, Hume and the Mind/Body Relation, in: History of Philosophy Quaterly, 17, 2000, str. 277-294, S. Traiger (vyd.), The Blackwell Guide to Hume's Treatise, Oxford 2006; A. C. Baier, A Progress of Sentiments, London 1991; J. Taylor, Reflecting Subjects, Oxford 2015; D. F. Norton, J. Taylor (vyd.), The Cambridge Companion to Hume, Cambridge 2019; P. Ardal, Passion and Value in Hume's Treatise; E. S. Radcliffe, Hume's Psychology of the Passions. The Literature and Future Directions, in: Journal of the History of Philosophy, 53, 2015, str. 565-606; G. J. Postema, „Cemented with Diseased Qualities“. Sympathy and Comparison in Hume's Moral Psychology, in: Hume Studies, 31, 2005, str. 249-298; J. McIntyre, The Idea of the Self in the Evolution of Hume's Account of the Passions, in: Canadian Journal of Philosophy, 42, 2012, str. 171-182. 
přičciny nebo účinky. Z nich vyvozujeme vášeň a tyto př́íčiny a účinky v důsledku toho vyvolávají naši sympatii." “6

Až na výjimky se zde nebudeme věnovat přechodu od příčin $\mathrm{k}$ vášním jako účinkům těchto př́íčin. Tento směr sympatie, který je důležitý i pro Humovu morální teorii, podle Huma umožňuje „sympatizovat“ s chirurgickým nástrojem jako příčinou bolesti pacientů či s hradbami města jako př́činou pocitu bezpečí jeho obyvatel. ${ }^{7}$ Náš výklad bude postupovat v druhém směru sympatie. Tématem bude ukazování se afektů jakožto př́čin $\mathrm{v}$ jejich tělesných účincích.

Bez ohledu na to, $v$ jakém směru prríčinnosti sympatie postupuje, platí, že př́íčinný soud vcítění má být podle Huma soudem analogickým, v němž hraje roli zkušenost o vztahu vlastních prožitků a jejich tělesných účinků ${ }^{8}$ a vztah podobnosti mezi myslí a tělem příslušníků téhož druhu. Podle Huma totiž platí, že ,příroda zachovala velkou podobnost mezi všemi lidskými bytostmi a očividně si nikdy nevšimneme vášně či principu u druhých lidí, pokud do nějaké míry sami v sobě nenalezneme jejich obdobu. ${ }^{\text {"9 }}$

Soud je zde, jak je to u Huma běžné, pouhým asociativním převedením živosti imprese na ideu, která je zprostředkovaná zprvu pre-reflektivním vztahem prŕččinnosti. ${ }^{10}$ Hume tedy soudem vcítění nemíní ani úsudek, tj. usuzování z premis na závěr, ani explicitní soud ve smyslu aktivního srovnání a spojení idejí podléhajících naší vůli. Analýza ,přirozeného" soudu vcítění spadá u Huma v druhé knize Pojednání do oblasti analýzy lidské obraznosti, jejíž principy vedou k asociativnímu vybavení a oživení ideje afektu druhé osoby. Převod živosti percepcí je přitom pasivní operací. Tuto přirozenou pasivitu Hume zdůrazňuje na mnoha klíčových místech Pojednání o lidské přirozenosti. Ve známém závěru

6 D. Hume, Pojednání, III, SB 576.

7 Tamt., II, SB 450, a tamt., III, SB 576.

8 Nakolik je mi známo, Hume nikde nevyjasňuje, odkud se bere toto vědomí o příčinné souvislosti vlastních vášní a jejich tělesných projevů a jakou má povahu. Bylo by však proti duchu Humovy filosofie chápat ho jako vrozené a nikdo takovéto pojetí, pokud vím, nezastává. Stojí také za povšimnutí, že např. Thomas Reid svou teorií vrozené souvislosti vášní a jejich výrazů útočí na empirismus, mezi jehož představitele počítá zejména Huma, viz T. Reid, On the Intelectual Powers of Man, London 1785, str. 597.

9 D. Hume, Pojednání, II, SB 318.

10 Pro pojetí soudu u Huma je klíčová jeho dlouhá poznámka pod čarou v Pojednání, I, SB 96-97. 
první knihy Pojednání, v níž autor ličí naprostou ztrátu přirozené víry navozenou reflexí nad dosaženými výsledky svých zkoumání, Hume podle všeho tvrdí, že soudy běžného životního postoje, a tedy i víry v duševní život druhých osob a bytostí, nelze trvale suspendovat, aniž bychom tím zároveň přišli o schopnost jednat a žít. ${ }^{11}$ Hume tedy, jak se zdá, nestaví do opozice přirozenou víru a solipsismus meditujícího filosofa, který pochybuje o existenci vnějšího světa či o tom, že může vědět, že druzí nejsou např. neoduševnělé stroje, nýbrž přirozenou víru a radikálně skeptické nalomení a - při trvalé „epoché“ - konečný rozklad smysluplné a ,životaschopné“ artikulace světa. ${ }^{12}$

Je ale také třeba upozornit na významný rozdíl mezi běžnou př́ičinnou inferencí a inferencí vcítění. Hume na mnoha místech zmiňuje, že originální imprese emoce druhého není nikdy dána, nemůžeme tedy mít tu zkušenost o uniformním souběhu cizích mentálních příčin a jejich tělesných účinků, v níž vidí Hume základ příčinného vyvození v běžném smyslu. Celá oblast mentálních prř́čin u druhých je zkušenosti nepřístupná a rozšriření naší zkušenosti o tuto oblast je proto zcela založeno v přenosu naší zkušenosti na cizí subjekt. ${ }^{13}$

Přirozená operace obraznosti, díky níž si živě vybavujeme ideje afektů druhých osob, je totiž pouhým základem operace, kterou Hume označuje za sympatii v př́ísném smyslu. A právě na tento aspekt se Hume zaměřuje, když zavádí pojem sympatie ve smyslu principu, který nám zpřístupňuje afekty druhého $v$ jejich impresionalitě a který již nepatří

11 Tamt., SB 268-270.

12 Viz A. Baier, A Progress of Sentiments, str. 17-43. Rozbor Humova pojetí radikální skepse a její vliv na Humovu teorii intersubjektivity přesahuje možnosti tohoto pojednání.

13 Anik Waldow ve své knize David Hume and the Problem of Other Minds (str. 66-73) navíc spatřuje problém v tom, že na jedné straně Humův princip abstrakce vyžaduje srovnání idejí jakožto kopií impresí a že, na straně druhé, nám jsou imprese druhého nepřístupné. Díky tomu bychom si nemohli utvořit obecný pojem mysli a pojmout sebe jako jednu z myslících osob mezi jinými, nebot' k jednomu případu mysli, a sice naší vlastní, nelze podle Huma připojit obecný termín. Lze snad odpovědět, že podle Huma pojímáme jisté ideje jako ideje druhého bez ohledu na jejich genetický původ v našich vlastních impresích. Imprese a ideje podle Huma samy o sobě ničím nepoukazují na nutnost být percepcí v naší mysli a jsou a priori myslitelné v oddělení od sebe navzájem i od naší vlastní mysli, viz D. Hume, Pojednání, I, SB 207. Kontrafaktuální představa, že numericky tatáž percepce, která je v mé mysli, by mohla být i v jiné, není podle Huma nijak problematická - percepce uvolněné v odhlédnutí od rozdílu vlastní/cizí by pak mohly tvořit základ pro zavedení obecného termínu ,percepce“. 
mezi principy obraznosti. Na první pohled není na Humově počáteční charakteristice sympatie nic zvláštního. Hume tvrdí, že:

„Nejpozoruhodnější vlastností lidské přirozenosti, jak svou vlastní povahou, tak svými důsledky, je náš sklon sympatizovat s druhými a sdílením získávat jejich postoje a pocity, at' již se od našich jakkoliv liší, či jsou vůči nim dokonce protikladné." ${ }^{14}$

Hume však netvrdí pouze, že díky sympatii rozumíme tomu, co prožívá druhý, nýbrž, a to je na celé věci nejdůležitější, že emoce druhého v sympatii spoluprožíváme:

„Pokud nám sympatie dodává afekt, poznáváme ho zprvu prostřednictvím jeho účinků a prostřednictvím těch vnějších znaků ve vystupování a konverzaci, které nám prostředkují jeho ideu. Tato idea se vzápětí proměňuje v impresi a získává takovou míru síly a živosti, že se z ní stává tato vášeň sama a že vytváří emoci, která se vyrovná jakémukoliv původnímu afektu..." ${ }^{15}$

Například idea radosti či smutku druhého se ve vcítění mění v impresi radosti či smutku druhé osoby. Je třeba si uvědomit, že když Hume hovoří o komunikaci osob, čili o „získávání postojů a pocitů, at' již se od našich jakkoliv lišî“", má na mysli toto sdílení impresí vášní samotných pomocí sympatie. Uchopení emoce druhého v soudu je zde jen podkladem, nikoli výsledkem sympatie. Pokud bychom navzájem uchopovali pouze ideje postojů a pocitů, nejednalo by se, jak uvidíme, o mezilidský vztah v běžném smyslu.

Proměna ideje v impresi není jediným původním rysem operace sympatie. Lidská přrirozenost se $\mathrm{v}$ oblasti sympatie dále vyznačuje tím, že afekce emocí druhého tíhne k emocionálnímu rozšîrení. Nejenže pocit’ujeme radost druhého, ale sami se začneme radovat. ${ }^{16}$ Tatáž tendence k rozšîrení emocí se týká i negativně laděných emocí, např. imprese smutku či bolesti druhého, které se mění v náš vlastní smutek a naši vlastní bolest.

Proč ale Hume hovoří o proměně ideje v impresi? Proč mu nestačí říci, že idea pojetí emoce druhého se v sympatii oživuje nebo že se její

\footnotetext{
14 D. Hume, Pojednání, II, SB 316.

15 Tamt., SB 317.

16 Tamt.
} 
Živost stupňuje, v tom smyslu, v jakém se v první knize Pojednání asociativně oživují a ve své živosti stupňují ideje našich smyslů? Tyto otázky se již týkají prvního přehlíženého aspektu Humovy teorie sympatie, o němž chceme - jak jsme si v úvodu předsevzali - pojednat.

Hlavní část naší odpovědi spočívá v tom, že „živost““, „oživování“ či „živé pojetî" mají v kontextu sympatie často jiný význam a hrají jinou roli než tytéž termíny v první knize Pojednání. Oživující vášnivost není totéž co oživující obraznost.

Abychom pochopili tento rozdíl, je třeba si všimnout, že idea emoce, kterou v druhé knize oživuje sympatie, $u z ̌$ je živá a silně pojatá ve smyslu první knihy Pojednání. Vybavujeme si ji totiž ve výše popsaném příčinném analogickém soudu, a ten je výkonem oživující obraznosti. Veselý obličej nás vede $\mathrm{k}$ víre $\mathrm{v}$ radost, kterou druhý prožívá. O této radosti nijak nepochybujeme. Této vášni rozumíme, ale necítíme ji. Hume totiž s idejemi vášní, které mají být kopiemi sekundárních impresí, zachází v kontextu sympatie často tak, jako by šlo o pouhé „zobrazení“ vášní. Zřejmě nejvýraznější pasáž, k níž se váže pojetí idejí vášní druhého jako pouhých zobrazení, je tato:

„Je skutečně zřejmé, že když sympatizujeme s vášněmi a pocity druhých, tato hnutí se v naší mysli nejprve objeví jako ideje a jsou pojata jako náležející jiné osobě právě tak, jako pojímáme jakýkoliv jiný fakt. Je také zřejmé, že ideje afektů druhých se proměňují právě v ty imprese, které reprezentují, a že vášně vznikají ve shodě s tím, jaký obraz jsme si o nich utvořili.“" ${ }^{17}$

Jelikož Hume hájí naprostou motivační impotenci rozumu vůči lidským vášním a lidskému jednání, ${ }^{18}$ nemůže živá představa vášně druhého sama o sobě vést $\mathrm{k}$ žádné emocionální reakci a $\mathrm{k}$ žádnému jednání na naší straně. Samotná prezentace vášní např. neumožňuje radovat se z toho, že druhý se raduje, či se vztekat, pokud je radost druhého škodolibostí zaměřenou na naši osobu. Živé ideje vášní samy o sobě neumožňují, abychom se k druhému vztáhli v soucitu či závisti, ani prostřednictvím jakékoli další emoce. Krátce řečeno, živá idea vášně, pokud nepodlehne proměně ve vášeň, neumožňuje ani konflikt, ani souznění emocí, které tvoří jednu ze základních oblastí běžných mezilidských vztahů:

17 Tamt., SB 319.

18 Tamt., SB 413-418, a tamt., III, SB 455-470. 
„I když jsou nám [vášně druhého známy], pokud by zůstaly pouze na úrovni obraznosti či pojetí, je tato schopnost natolik uvyklá na předměty rozmanitých typů, že pouhá idea, přestože odporuje našim pocitům a sklonům, by na nás sama o sobě nikdy nemohla zapůsobit.“"19

Idea vášně tedy není tím, čemu Hume říká klidná vášeň čili vášeň, na kterou jsme si zvykli tak, že o ní ani nevíme, přestože prosycuje náš každodenní život. Není ani tím, co Hume nazývá slabou vášní, tj. vášní, která v konfliktu rychle podlehne jiné vášni. Živá idea vášně druhého není v kontextu sympatie zkrátka vůbec vášní, nýbrž zobrazením této vášně.

Důvod, proč naše čtení není nijak běžnou součástí výkladů Huma, spočívá v tom, že Hume se často vyjadřuje tak, jako by idea vášně byla již sama slabou vášní a jako by sympatie slabě pojatou vášeň pouze posilovala. To je však způsobeno tím, že proměna ideje vášně v impresi je podle Huma ve výkonu sympatie tak automatická a pasivní, že odlišit, zda jde ještě o ideu, anebo už o impresi vášně, lze mnohdy jen ,umělou“ filosofickou analýzou. Je třeba vzít také v potaz, že čím je idea vášně živější, tím bezprostřednější a snazší je i její proměna v impresi vášně. Hume sám píše, že „at' již je ale tato změna ideje v impresi jakkoliv náhlá, pramení z jistých ohledů a uvážení, které neujdou podrobnému zkoumání filosofa, i když mohou unikat osobě, která je vykonává.“20

Při vcítění má však podle Huma docházet právě k pocit’ování vášní a emocí druhých. Jak k tomuto vcítění dochází a odkud pochází živost, která z živé ideje vášně učiní vášeň samotnou? Hume odpovídá poněkud překvapivě. Zdrojem živosti je imprese našeho vlastního já (self) čili vědomí vlastní osoby:

„Př̀i sympatii zjevně dochází k proměně ideje v impresi. Tato proměna vzniká na základě vztahu předmětů k našemu já. Naše já je nám vždy bezprostředně přítomné.“21

19 Tamt., III, SB 593.

20 Tamt., II, SB 317.

21 Tamt., SB 320. Zajímavým důsledkem této teorie je, že když percepce já není dostatečně živá, ztrácíme schopnost se do druhých vcitovat a mechanismus sympatie se zastaví u pouhého představování emocí druhých lidí. Oživování vlastního já popisuje Hume prostřednictvím své teorie nepřímých vášní, viz níže. 
„... naše vědomí nám poskytuje tak živé pojetí naší vlastní osoby, že si ani neumíme představit nic, co by ho mohlo v tomto ohledu překonat. Každý předmět spřízněný s naším já musí tedy být podle předcházejících principů představen s podobně živým pojetím..."22

Imprese vášně, která jejím oživením vzniká, není kopií ideje vášně, nýbrž její metamorfózou na základě těsného vztahu k vlastnímu já, které této ideji udílí živé pojetí. Toto spříznění emoce druhého s vlastním já čili s vlastní osobou probíhá podle Huma na několika rovinách.

První nutnou, nikoli však dostatečnou podmínkou je již zmiňovaná druhová podobnost. Hume běžně ve svých teoriích využívá vcit'ování do zviřrat a jeho příklady přitom vždy poukazují na chování, které se podobá lidskému. $\mathrm{Z}$ tohoto hlediska je nejpodobnějším zvîretem druhý člověk. Podobnost zde ovšem nejen usnadňuje postřehnutí vášní druhého ve smyslu vyvolání příslušné ideje, nýbrž uvádí také tuto ideu do těsnějšího vztahu k vlastnímu já. Čím podobnější je bytost, do níž se vcit’ujeme, tím snáze se s ní „spř́izníme“ a tím silněji její mentální život pocit'ujeme. Hume dále zmiňuje kulturní podobnost mezi chováním příslušníků stejného národa - tj. podobnost jazyka, konvencí, obyčejů či tzv. národních povahových rysů. S krajany sympatizujeme podle Huma živěji než s cizinci. ${ }^{23}$

Kromě právě popsané podobnosti zmiňuje Hume také soumeznost ve smyslu prostorové blízkosti - snáze a živěji jsou nám přístupné pocity a hodnocení sousedů, zatímco emoce vzdálených lidí jsou obvykle zakoušeny jako slabé. Nakonec Hume zahrnuje do vztahů spříznění i vztah

22 Tamt., SB 317. Jak smířit na první pohled protichůdná Humova vyjádření týkající se imprese já v první a druhé knize a tichý přechod od já, které občas splývá se souborem obsahů lidské mysli, k já, které je osobou se zájmem o sebe sama, je předmětem rozsáhlé diskuse. K tomu viz např.: J. McIntyre, Personal Identity and Passions, in: Journal of the History of Philosophy, 27, 1989, str. 545-557, a T. Penelhum, The Self of Book 1 and the Selves of Book 2, in: Hume Studies, 18, 1992, str. 281-292.

23 Pravidelnost a podobnost chování dále umožňuje vznik obecných pravidel, která mají normativní povahu. Vášně se díky nim při sympatii jeví jako přiměřené, nepřiměřené, vhodné či nevhodné. V druhé knize Pojednání Hume upozorňuje na to, že díky těmto pravidlům velmi živě sympatizujeme s druhým i zástupně s ohledem na situaci, kterou druhý neprožívá tak, jak má,tj. jak by ji prožíval normální dospělý člověk za normálních okolností. Dotyčný nap̌r. spí pod stromem, a přitom na něj běží stádo koní (D. Hume, Pojednání, II, SB 385), či je šílený a jedná nepatřičně (tamt., SB 371), nebo se jedná o dítě, které nerozumí své situaci (malý princ bezstarostně si hrající se svými nepřáteli, tamt.). 
př́činnosti - s prožitky vlastních rodinných příslušníků sympatizujeme Živěji. ${ }^{24}$

Dříve než přejdeme k sociálnímu rozměru sympatie, zastavme se na chvíli u Humovy teorie šr̂rení emocí. Zde je třeba ostře odlišit „naše imprese cizí vášně“ a „naše imprese vlastní vášně“. Všechny imprese jsou naše $v$ tom smyslu, že patří do svazku percepcí, které tvoří naši mysl, a v tomto smyslu se všechny (naše) ideje vášní druhého stávají díky operaci sympatie našimi impresemi. Bylo by však absurdní tvrdit - a Hume to ani nečiní -, že při vcítění do radosti druhého se již v prvním kroku stáváme osobami, které se radují. Např. celý důležitý princip srovnávání se u Huma zakládá na tom, že přirozeně srovnáváme svou situaci se situací druhého. Na základě tohoto srovnání je často první reakcí na cizí štěstí bolestná závist a na cizí neštěstí radostná škodolibost. ${ }^{25}$ Princip srovnání však není tak fundamentální jako princip sympatie, v němž se vášně druhého stávají našimi vášněmi, protože podle Huma princip srovnávání předpokládá princip sympatie. Cizí štěstí či neštěstí nás musí zasáhnout, tj. musí vyvolat impresi, pokud máme závistivě či škodolibě reagovat.

Reakce pramenící ze srovnání je pak reakcí i v druhém, silnějším smyslu. Podle Huma totiž překonává náš původnější sklon podléhat cizím vášním. $\mathrm{K}$ podobnému zvratu dochází i tehdy, když nás osoba, do níž se vcit'ujeme, poškodila, a vyvolala tím naši touhu po pomstě. ${ }^{26}$ Hume však rozhodně tvrdí, že naší přirozenější prvotní reakcí na vynoření imprese cizí vášně je její „rozšřření“" v impresi naší vlastní vášně. V tomto smyslu nás sympatie vždy vystavuje jistému asymetrickému tlaku ke konformitě či emocionálnímu sladění:

„[Převzetí názorů a pocitů] je patrné nejen u dětí, které bezmyšlenkovitě přijímají všechny názory, které se jim předkládají, ale také u nejsoudnějších a nejchápavějších lidí, kteří se jen s obtížemi drží vlastního rozumu a náklonností, pokud odporují těm, které mají jejich přátelé a každodenní společníci.“27

24 Srv. D. Hume, Pojednání, II, SB 318.

25 Velmi detailní popis tohoto principu a jeho funkce v Humově filosofii poskytl G. J. Postema, „Cemented with Diseased Qualities“. Sympathy and Comparison in Hume's Moral Psychology.

26 D. Hume, Pojednání, II, SB 366-368.

27 Tamt., SB 316. 
Hume tedy postuluje pouze základní sklon k přejímání pocitů druhých a v právě uvedeném citátu jej propojuje tak silně se sklonem $\mathrm{k}$ sympatii, že oba principy takřka splývají.

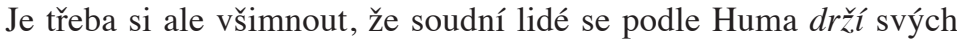
pocitů, byt' jen s obtížemi, tj. nepřebírají automaticky pocity svých přátel - vždyt' právě v obecném a pevném hledisku se ukazuje jejich soudnost -, a že pokud osoby, do nichž se vcit'ujeme, prátelé nejsou, či se dokonce jedná o nepřátele, může být sklon k emocionálnímu podlehnutí slabý či zcela potlačený, aniž by byla zároveň potlačena operace vcítění:

„Princip sympatie je svou přirozeností natolik mocný a pronikavý, že vstupuje do většiny našich pocitů a vášní a často vystupuje v podobě svého protikladu. Je pozoruhodné, že když se proti mně někdo staví ve věci, na které mi silně záleží, a svou opozicí vyprovokuje mou vášeň, vždy s ním do jisté míry sympatizuji a moje rozrušení pochází se stejného zdroje.“ ${ }^{28}$

Právě proto, že Hume považuje sklon k převzetí cizích pocitů za přirozenou součást sympatie, může s termínem ,sympatie“ operovat v užším smyslu sdílení impresí druhého. Opakem této sympatie je pak antipatie ve smyslu prožívání vášní, které stojí v protikladu vůči těm, jež nám vnukává humovská sympatie vzatá v širším smyslu. Cizí radost pak např́klad působí náš vlastní smutek a naopak. To však nemění nic na tom, že antipatie pramení ze sympatie $\mathrm{v}$ širším smyslu konverze ideje vášně v její impresi. Cizí radost musím zakusit jako impresi, abych na ni mohl reagovat impresí smutku.

\section{Sympatie a nepřímé vášně}

Potom, co jsme řekli o významu sympatie v Humově systému, by čtenář čekal, že v jeho knize nalezne samostatnou kapitolu, která se principu sympatie věnuje. Tak tomu však není. Hume zavádí sympatii v kapitole, jež nese název Láska ke slávě. Tento překvapivý postup je nyní třeba vysvětlit.

Hume tento princip zavádí, aby vysvětlil vnímání chvály a hany vlastní osoby. Hlavním cílem v druhé knize Pojednání je totiž pomocí sympatie navzájem propojit nepř́ímé vášně osob. Čím se u Huma vyznačují

28 Tamt., III, SB 593. 
nepřímé vášně? Na rozdíl od přímých vášní, jako je radost či smutek, které mají jen jeden předmět, zakoušíme v nepřímých vášních souvislost dvou předmětů - libě či nelibě zakoušeného předmětu, který je vyvolává, a libě či nelibě zakoušeného předmětu, na který jsou zaměřeny. Tyto vášně jsou také ze své přirozeností personální. Předmět, na nějž jsou zaměreny, je totiž jen vlastní anebo cizí já. A toto já jednání či zájmu o sebe sama zakoušíme jako předmět pouze jako já libé či nelibé. Na některých místech Pojednání se dokonce zdá, že toto já je v nepřímých vášních vytvářeno a neexistuje mimo ně. ${ }^{29}$

Hume neprrímé vášně dále specifikuje následujícím způsobem. Své vlastní já zakoušíme libě či nelibě v pýše a studu, cizí já pak zakoušíme jako libé či nelibé v lásce a nenávisti. ${ }^{30}$ Libost či nelibost vášně, jejímž předmětem je já, je vyvolána spřízněním s libostí či nelibostí předmětu, který zapřríčiňuje nepřímou vášeň. Přričinou nepřímé vášně může být nějaký libý či nelibý předmět jen tehdy, jestliže se k osobě nějak váže, jestliže mezi ním a osobou panuje nějaký užší vztah. Příčiny nepřímých vášní pak Hume seřazuje do jakýchsi koncentrických kruhů. ${ }^{31}$ Např. nejniternějšími libými příčinami jsou vlastnosti mysli - vtip, pamět', bystrost, morální ctnosti, dále následují vlastnosti těla - krása, síla, hbitost apod. Nakonec Hume pojednává o vnějších příčinách nepřímých vášní - jedná se zejména o rod, slávu, postavení a v neposlední řadě bohatství a majetek.

Proč je však princip sympatie zaveden v rámci analýzy nepřímých vášní? Hume zdůrazňuje, že i když pýcha a stud mají přirozený základ, v pravém smyslu je nikdy nepocit'ujeme v izolaci. Vždy jistým způsobem libě či nelibě pocit'ujeme vlastní já v rámci vcítění do toho, jak na nás hledí druzí, a oni naopak prožívají sebe sama v rámci vcítění do toho, co k nim cítíme a jak jejich situaci vidíme my. Sympatie umožňuje toto propojení a sdílení nepřímých vášní právě tak, jako umožňuje komunikaci přímých vášní. Díky této komunikaci můžeme realizovat jednu ze základních potřeb, a sice potřebu sympatie ve smyslu souznění:

29 Pečlivou argumentaci pro tuto tezi nabízí např. A. O. Rorty, „Pride produces the idea of self“. Hume on moral agency, in: Australasian Journal of Philosophy, 68,1990 , str. 255-269.

30 „Pýcha“, „,stud“, „láska“a „,nenávist“ jsou u Huma technické termíny pro libé a nelibé pocity, jejichž význam je oproti každodennímu významu velmi rozšířen, takže zahrnují veškeré libé a nelibé pocit’ování vlastního či cizího já. Vynikající popis technického užití těchto termínů u Huma poskytl P. Ardal, Passion and Value in Hume's Treatise, str. 17-40.

31 D. Hume, Pojednání, II, SB 294-316. 
„Nedokážeme si vytvořit žádné přání, které by nás neodkazovalo na společnost, naprostá samota je možná tím nejhorším, čím můžeme být potrestáni. Každé potěšení pocit'ované v odloučení od společnosti bledne a každá bolest je krutější a nesnesitelnější. At' již námi hýbou jakékoliv další vášně - pýcha, ctižádost, hrabivost, zvědavost, pomstychtivost nebo slast - duší, neboli hybným principem jich všech je sympatie a kdybychom zcela abstrahovali od myšlenek a pocitů druhých, neměly by žádnou sílu.“32

Lidská mysl a personální já jsou díky sympatii vpleteny do společného sdílení př́imých a nepřímých afektů, které Hume přirovnává k zrcadlení a v němž hrají nepřímé vášně ústřední roli:

„... mysli lidí jsou vzájemnými zrcadly nejen kvůli tomu, že odrážejí vzájemné emoce, nýbrž také kvůli tomu, že paprsky vášní, citů a postojů se často vrací s ozvěnou a mohou postupně odeznívat v neznatelných krocích.“33

Má radost se zračí v radosti bližního, z čehož mám potěšení, které druhého opět těší. Všechny sdílené emoce mají v sympatii své ozvěny a lidský život je v tomto zřetězení a zrcadlení přirozeně společenským životem.

\section{Sympatie a tělo druhého}

Nepostradatelnou podmínku ustavení celé této oblasti našeho života tvoří u Huma tělesnost, která nám ukazuje prožitky druhých a naše prožitky ukazuje jim. Zde interpret naráží na složitou otázku, jak - s přihlédnutím k velkému významu, jenž přísluší vcit'ujícímu sdílení vášní - podle Huma vypadá či může vypadat struktura zkušenosti s tělem druhého jakožto zkušenosti s tělem duševně prožívající osoby.

Protože v právě vznesené otázce používáme termín „tělo“ (body), je nejprve vhodné rozlišit mezi různými hlavními významy tohoto termínu v Humově Pojednání. Nerozlišování různých kontextů, v nichž je termín

32 Tamt., SB 363. Tuto stránku Humova myšlení rozpracoval a zdůraznil ve své pozoruhodné analýze vcitování Humův prŕítel Adam Smith, viz první čtyři kapitoly jeho knihy The Theory of Moral Sentiments, London 1761, str. 1-29.

33 D. Hume, Pojednání, II, SB 365. 
„tělo“ u Huma používán, by mohl vést k nesprávnému pohledu na problematiku, kterou mají jeho teorie řešit. Dodatečnou výhodou těchto rozlišení je, že je lze využít i při jinak zaměřených analýzách Humova textu.

a) Tělo ve smyslu tělesa. V tomto ohledu je u Huma tělo prostorovým útvarem, který se nijak zvlášt' neliší od jiných prostorových věcí. Realitu těla podmiňuje, kromě umístění v čase a prostoru, jeho začlenění do zákonitých příčinných vztahů s jinými předměty. ${ }^{34}$

b) Fyziologické tělo. Jedná se o tělo, jehož životní a jiné funkce popisují podle Huma lékaři a anatomové. Pro Huma má toto tělo značný význam: v jeho systému představuje nutnou př́činnou podmínku všech našich percepcí, „nebot' všechny naše percepce závisí na našich smyslových orgánech a na dispozici našich nervů a životních hybatelů." ${ }^{35}$

c) Osobní tělo. Jedná se o naše tělo a těla druhých tak, jak jsou zakoušena, když zakoušíme sebe a druhé jakožto osoby v běžném životě a jednání. Vnímání mého těla a těla druhých osob pak má u Huma tři hlavní dimenze:

c1) Perceptivní tělo. Tělo jak ho odhaluje smyslové vnímání. O tomto těle hovoří Hume jako o komplexní percepci. ${ }^{36}$

c2) Výrazové tělo. Vnímání těla druhých nám kromě jeho tvaru, velikosti a ostatních tělesných vlastností ukazuje „emocionální“ vzezření (countenance), ${ }^{37}$ vystupování (air, comportment), rysy (features), tón hlasu apod. Tělo je zde tedy orgánem sdílení pocitů, postojů a názorů apod. Hume termín „sdílení“ (communication) běžně používá právě pro označení vzájemného předávání a sdílení pocitů a postojů osob v tělesných výrazech a v tělesném jednání.

c3) Tělo nepřímých vášní. Tělo patří spolu s myslí k příčinám pýchy a studu, které jsou s námi nejúžeji spjaty, a naše tělo je předmětem lásky či odporu druhých. Hume proto neváhá toto tělo zahrnout do širšího pojmu já jakožto zdroje slasti či strasti ze sebe sama. Toto tělesné a myslící já je tím já, za které se ve svých očích a v očích druhých stydíme či ze kterého se radujeme, a je zároveň příćinou zalíbení či odporu druhých

34 Viz příklad s poslíčkem. Tamt., I, SB 196.

35 Tamt., SB 211. Hume sám se fyziologickému popisu př́ičin smyslových percepcí a asociací percepcí záměrně takřka nevěnuje, ale zjevně je ve svém systému předpokládá, viz tamt., SB 8, 60, 248, a tamt., II, SB 275-276. Fyziologický rozměr percepcí a jejich asociací zdůraznil J. P. Wright. Viz J. P. Wright, Hume’s „A Treatise of Human Nature“, Cambridge 2009, str. 51-57, 71-74, 114-115, 122-126.

36 Viz D. Hume, Pojednání, I, SB 191.

37 Viz např. tamt., II, SB 304, 317, a tamt., III, SB 594. 
lidí. Tělo nepřímých vášnî ${ }^{38}$ je tedy v tomto kontextu příčinou sympatie ${ }^{39}$ a Hume se ho nerozpakuje zasadit i do sexuálního kontextu. ${ }^{40}$ Toto tělo jako př́čina potěšení značí potěšení jinak než tvář, jejíž výraz je účinkem potěšení.

V naší otázce po ukazování těla druhých osob nám půjde o tělo druhého ve výrazovém ohledu, nikoli o fyziologické změny nervů a svalů uvnitř těla zapříčiněné našimi vášněmi. A právě v pojetí výrazového těla narážíme v Humově teorii na vážné problémy.

I když odhlédneme od věrohodnosti popisu oživování emoce živostí vlastního já, zdá se, že Humova teorie čelí námitkám, jež proti vcitování na základě analogického soudu vznáší zejména fenomenologie. ${ }^{41}$ Tělo druhého není přece indikátorem mentálního života druhého tak, jako je kouř na obzoru indikátorem ohně za obzorem. Při interakci s druhou osobou neschází v jevu mentální polovina této osoby, jejíž nepřítomnost by musel suplovat povrch a pohyb těla fungující jako pouhý ukazatel něčeho skrytého. Podle Humovy teorie příčinnosti by navíc mezi emocemi a jejich vyjádřením musel být vztah časové následnosti příčiny a účinku. Lze však jen stěží tvrdit, že se vždy nejdříve zaradujeme „pro sebe“, načež teprve naváže náš úsměv jako viditelný účinek pro druhé. Psychický život druhého není jakousi schránkou, do které se nikdy nelze podívat. Spíše se zdá, jak tvrdí mnozí fenomenologové, že duševní a tělesná stránka osoby je v jevu druhému nějak přítomna současně a bezprostředně. Prožívání druhého jistým způsobem vidime či zakoušíme na něm samotném, v jeho tělesné přítomnosti. Právě fenomenologie si položila naplno otázku, jakou má tato intuitivní zkušenost strukturu.

Hume si tuto otázku explicitně nepoložil. Chceme zde přesto hájit tezi, že byl prŕliš bystrý pozorovatel na to, aby nechal v Pojednání o lidské prrirozenosti tento problém zcela stranou. Jedná se sice o pouhá

38 Tamt., III, SB 614.

39 Podobně jsou u Huma hradby příčinou sympatie s pocitem bezpečí obyvatel města (tamt., II, SB 450) a chirurgické nástroje příčinou sympatie se strachem pacientů (tamt., III, SB 576). Podle Huma je tedy sympatie vyvolávána i pojetím předmětů jako příčin pocitů, popř. pohledem na tělo či mysl jako příčiny libosti a nelibosti. Tento rozměr sympatie není pro téma, jež budeme dále rozebírat, relevantní.

40 Tamt., III, SB 614.

41 Ke shrnutí některých základních bodů fenomenologické kritiky tradičního kartesiánského pojetí vcit'ování jako analogického soudu v současném kontextu filosofie mysli viz P. Urban, Jak rozumíme druhým, Praha 2016. Část této kritiky lze mutatis mutandis uplatnit i na nedualistické teorie sympatie pracující s analogickým soudem ve smyslu analogizující pasivní asociace. 
rudimentární a nerozpracovaná východiska možného řešení. Dosledování jejich intencí však vede k výsledku, který je hoden zaznamenání. Některé prvky Humovy oficiální teorie percepcí totiž narušují zdánlivou samozřejmost výše popsané přičinné teorie vcítění a v některých bodech vzniká mezi oběma napjatý vztah, případně i rozpor.

Je totiž třeba položit si otázku, jak se u Huma do pojetí a víry týkajících se prožitků druhého promítá samotná povaha vášní jakožto neprostorových percepcí. Hume - a tento bod bývá přehlížen - zavádí v Pojednání obecný princip kvazi-lokalizace všech neprostorových percepcí, a tedy i vášní, v prostoru. Výsledek kvazi-lokalizace Hume navíc popisuje jako začlenění vlastnosti do rozprostraněného předmětu. Jelikož neprostorové percepce musí být vztaženy k prostorovému nositeli jako jeho vlastnosti, musí být vášně jako vlastnosti kvazi-lokalizovány do prostorového těla osoby. Kvazi-lokalizované vášně proto vystupují jako mody předmětů a nikoli jako termíny komplexních relací, které Hume vidí jako relace mezi předměty. ${ }^{42}$

V následující kritice budeme postupovat následovně: Nejprve upozorníme na některé rysy Humovy teorie percepcí, které se u Huma týkají vztahu těla a duše. Tento výklad nás dovede k problematice vztahu neprostorových a prostorových percepcí. Hume, jak uvidíme, řeší tento problém pomocí principu fiktivního ztělesnění neprostorových percepcí smyslů. Nakonec budeme argumentovat pro tezi, že stejné řešení Hume připouští i v oblasti neprostorových percepcí vášní. Na základě tohoto argumentu nastíníme možné pojetí tělesného ukazování vášní u Huma.

\section{Percepce a prostorovost}

Hume, jak známo, tvrdí, že ,můžeme pozorovat, že to, co nazýváme myslí, není nic než kupa či soubor různých percepcí“.43

Celý metafyzický pojem substance jakožto trvajícího nositele vlastností je pak v Humově Pojednání explicitně označen za fikci. ${ }^{44}$ Fikcí je tedy i ontologický dualismus substancí a pojetí mysli jako nositele vlastností. Hume ovšem také říká, že pokud bychom chtěli zvolit omezenou

42 K diskusi o rozdílu mezi mody a relacemi viz D. Hume, Pojednání, I, SB 14-17.

43 Tamt., SB 207. Tuto redukci je třeba chápat s rezervou, nebot' Hume mysli připisuje také přirozenost, tj. faktické zákony operací s percepcemi, sklony a původní instinkty.

44 Tamt., SB 232. 
definici substance a tvrdit, že substance je čistě to, co - teoreticky vzato - může existovat samo o sobě, mohli bychom každou percepci považovat za substanci:

„... jelikož jsou všechny naše percepce různé jak od sebe navzájem, tak od všeho dalšího ve vesmíru, jsou také odlišné a oddělitelné, mohou být uvažovány jako samostatně existující, mohou existovat samostatně, a nepotřebují tedy žádnou oporu své existence. Jestliže tato definice vystihuje substance, jedná se tedy o substance.“45

Pokud ovšem tato definice substanci nevystihuje, pak percepce nejsou substancemi. Je tedy zjevné, proč se Hume odmítá zabývat tím, zda má mysl hmotnou či nehmotnou povahu. Pod titulem metafyzické diskuse vztahu vůle a jednání sice Hume následně řeší některé body kartesiánské problematiky vztahu mysli a těla, její větší část však odmítá jako nesmyslnou a zbytek převádí na půdu své asociativní psychologie:

„Percepce podle všeho ke své existenci žádnou podporu nevyžadují. Nemáme tedy žádnou ideu inherence. Jak tedy můžeme odpovědět na otázku, zda percepce inherují ve hmotné, či nehmotné substanci, když vlastně smysl otázky ani nechápeme?"46

Tradiční otázka po vztahu duše a těla se u Huma nakonec proměňuje v otázku po relacích mezi percepcemi prostředkujícími ideu prostoru a neprostorovými percepcemi ${ }^{47}$ Hume sám řadí k „,prostorovým“ percepcím pouze percepce zraku a hmatu, všechny ostatní percepce sice existují, samy o sobě však existují pouze někdy, nikoli někde:

„Prvotní představu o prostoru a rozprostraněnosti nám ze smyslů poskytuje výhradně zrak a hmat a nic kromě toho, co je barevné nebo hmatatelné, nemá části uspořádané tak, aby nám tuto ideu zprostředkovalo... A nyní vyhlásím zásadu, kterou někteří metafyzici zavrhují a o níž se má za to, že odporuje nejjistějším principům lidského

45 Tamt., SB 233.

46 Tamt., SB 234.

47 Přísně vzato se jednoduché percepce nedělí na prostorové a neprostorové. Prostor odhalovaný percepcemi, které bereme samy o sobě, je pro Huma řádem percepcí hmatu a zraku, viz D. Hume, Pojednání, I, SB 34. Tento řád nemůže prostředkovat žádná nesložená percepce, a Hume tedy prostorovost upírá všem jednoduchým percepcím. 
rozumu. Tato zásada tvrdí, že předmět může existovat, aniž by někde byl. $\mathrm{K}$ tomu dodávám, že je to nejen možné, ale že i většina $\mathrm{z}$ toho, co existuje, existuje a musí existovat tímto způsobem."“8

Vně těla se neprostorové percepce nejeví být kvůli funkci smyslového vnímání, nýbrž kvůli operacím obraznosti. Tak jako věříme, že světské předměty jsou identicky trvající, nezávislé a koherentně uspořádané v neměnných reálných vztazích přičinnosti, věříme podle Huma, že fenomenální předměty se všemi svými smyslově zakoušenými vlastnostmi jsou vůči tělu prostorově vnější. Teprve ve filosofické reflexi se ukazuje, že tuto víru nelze odůvodnit ani smysly, ani rozumem. Filosofovi nezbývá než principy obraznosti $v$ jejich rozmanitosti obecně popsat a, nakolik je to vůbec možné, sjednotit. Jak tedy fiktivní vztažení neprostorových percepcí do prostoru podle Huma probíhá?

\section{Kvazi-lokalizace neprostorových impresí}

Úkaz kvazi-lokalizace neprostorových percepcí, ${ }^{49}$ tj. to, že tyto percepce míníme s místními určeními, které ze své povahy nemohou mít, vysvětluje Hume v první knize Pojednání o lidské přirozenosti..$^{50}$ Dříve než se pustíme do dalšího výkladu, vytkněme několik bodů. Hume sám říká, že „otázka prostorového spojení předmětů se nevynořuje pouze v metafyzických sporech o přirozenosti duše“, nýbrž že i ,v každém okamžiku běžného života máme př́ležitost $\mathrm{k}$ jejímu zkoumání“ “. ${ }^{51}$ Hume tím ohlašuje právě přechod $o d$ metafyzického zkoumání povahy duše, tj. od otázky, zdali je duše sama o sobě hmotná, či nehmotná a jak mohou duše a hmota souviset $\mathrm{v}$ prostoru a vzájemně na sebe působit, ke krátkému zkoumání naší každodenní víry v prostorovost neprostorových percepcí. Pro diskusi kvazi-lokalizace volí Hume jako vzor entit, které se nikde nenalézají, percepce chuti:

48 D. Hume, Pojednání, I, SB 235.

49 Hume sám termín kvazi-lokalizace nepoužívá, dobře však vyjadřuje jev, o který se Humovi jedná.

50 Oddíl Nehmotnost duše, D. Hume, Pojednání, I, SB 232-251. Termín kvazi-lokace není Humův, přesně však vystihuje jeho myšlenku. Proto jej zde zavádíme jako pomocný interpretační termín.

51 D. Hume, Pojednání, I, SB 256. 
„Předpokládejme tedy, že na jedné straně stolu vidíme ležet fík a na druhé olivu. Když si představujeme složené ideje těchto substancí, patří očividně mezi nejnápadnější idea jejich rozdílné chuti. Právě tak očividně tyto vlastnosti sjednocujeme a spojujeme s barevnými a hmatovými vlastnostmi. Hořká chut' olivy a sladká chut' fíku se mají nacházet v samotných viditelných tělesech a má je vzájemně oddělovat celá délka stolu." ${ }^{52}$

Věříme, že chut' olivy a fíku je soumezná (contiguous) s prostorem, který fík a oliva zaujímá. ${ }^{53}$ Tuto fikci spočívající v tom, že umist'ujeme chut' do objemu fíku či olivy, Hume vysvětluje přirozeným sklonem lidské mysli k vzájemnému doplňování různých typů základních vztahů asociace. Jeden typ asociace se může přidat k navyklému spojení a toto spojení posílit, aniž by byl opřen o minulou zkušenost. Hume vše vysvětluje takto:

„Chut' a pach ovoce nelze oddělit od jeho ostatních barevných a hmatových vlastností, a at' je příčinou nebo účinkem kterákoliv z nich, nepochybně existují vždy pospolu. Tyto vztahy př́ícinnosti a časové soumeznosti, v nichž se jeví rozprostraněný předmět a vlastnost, která se nenachází na žádném konkrétním místě, musí na mysl účinkovat tak, že když se jeden z nich objeví, mysl okamžitě zaměří myšlenku na představu druhého. To však není vše. Nejenže na základě jejich vztahu obracíme naši myšlenku z jednoho na druhé, nýbrž také se snažíme vztáhnout je k sobě novým způsobem, a sice vztahem prostorové soumeznosti, abychom tento přechod usnadnili a dodali mu na přirozenosti. “" 54

Tím se ovšem Hume dostává do velmi obtížné situace. Byt' hovoří o jistých vlastnostech fíku jako příčině jeho chuti, jeho chut' jakožto jeho vlastnost není následným účinkem barevných či hmatových vlastností fíku jako předmětu, ani zde není účinkem jeho skryté chemické struktury, nebot' neznalost této struktury nijak nebrání tomu vztáhnout chut' fíku k jeho tvaru. Podle Huma by chut' měla existovat jakožto vlastnost časově soumezně s ostatními prostorovými vlastnostmi fíku, vždyt' ,nepochybně existují vždy pospolu“. Nejedná se tu o přehlédnutí. Hume

\footnotetext{
52 Tamt., SB 237.

53 Tamt., SB 238.

54 Tamt., SB 237.
} 
zavádí příčinný vztah také mezi mody předmětů, a nikoli jen mezi předměty v př́ísném smyslu již na začátku první knihy Pojednání:

„... jednotlivé kvality, které utváří substanci, jsou obvykle vztahovány k neznámému čemusi, v němž mají inherovat, anebo pokud připustíme, že k této fikci nedochází, mají být alespoň těsně a neoddělitelně spojeny vztahy soumeznosti a př́íčinnosti.“"55

Př́činnost jako vztah mezi predměty podle Huma ale předpokládá časovou následnost předmětů, nikoli jejich současnost. Př́činnost v Pojednání vyžaduje také prostorovou soumeznost. I ta je zde ale vyloučena, protože prostorová soumeznost neprostorových a prostorových percepcí má být předmětem víry teprve na základě prŕícinnosti. Podle definic $P o$ jednání by tedy žádná neprostorová percepce nemohla být vůbec př́ícinou, nebot' nemůže být s ničím prostorově soumezná ${ }^{56}$

Nakonec musíme zdůraznit i to, že fikce prostorové soumeznosti neprostorových percepcí v prostorových, kterou mysl vytvárí z vlastních zdrojů, nemá skoro nic společného se soumezností mezi předměty, jak ji definuje první část první knihy Pojednání. Nevěříme, že chut' a prostor se dotýkají v prostoru, ani že jejich části jsou $\mathrm{k}$ sobě nějak jednoznačně přiřazeny. Podle Huma za normálních okolností věříme, že chut' fíku fík plně proniká či prosycuje, aniž by se dělila na části:

„Předpokládáme sice, že chut' se nachází uvnitř obvodu tělesa, ale tak, že vyplňuje celek, aniž by byla rozprostraněná, a nachází se v každé části bezezbytku a nedělitelně. Krátce řečeno, v našem nejobvyklejším způsobu myšlení užíváme scholastický princip totum in toto et totum in qualibet parte, který vyslovímeli ho bez obalu, zní zcela neuvěřitelně. “57

\section{Tamt., SB 16.}

56 Domnívám se, že tato závažná a poměrně zjevná strukturální chyba v Pojednání, spíše než Humovo zohlednění gravitace čili působení na dálku (srv. J. Hill, Hume's Theory of Causation. Is There More Than One?, in: Teorie vědy, 33, 2011, str. 233-249), je důvodem, proč Hume vypustil ve Zkoumání o lidském rozumu prostorovou soumeznost z definice prř́činy. Oba tyto motivy se samozřejmě nevylučují a mohly působit současně. Na tutéž argumentaci jsem narazil v článku: A. Baier A. Waldow, A Conversation between Annette Baier and Anik Waldow about Hume's Account of Sympathy, in: Hume Studies, 34, 2008, str. 61-87, viz zejm. str. 67.

57 D. Hume, Pojednání, I, SB 238. 
Mohlo by se zdát, že zde rozebíráme nepodstatné detaily. Nesmíme však zapomenout, že drtivá většina obsahů naší mysli není podle Huma prostorově uspořádána a neumožňuje nám získat ponětí o prostoru. Otázka jejich začlenění do prostorového řádu je proto pro Humovu analýzu každodenního postoje nesmírně důležitá.

\section{Kvazi-lokalizace vášní u Huma}

Nezbývá než se zeptat, zdali podle Huma vášně (sekundární percepce) - jež všechny pokládá za neprostorové - podléhají podobné kvazi-lokalizaci v tělesných znacích, s nimiž jsou asociovány, a to právě tak, jako jsou primární neprostorové percepce kvazi-lokalizovány v asociovaných prostorových vlastnostech těles. Není žádný důvod, proč by tomu tak nemělo být. Hume sice udává v celé diskusi kvazi-lokalizace pouze jeden prríklad s percepcí chuti, ale jeho argumenty mají podle všeho platit pro celou třídu neprostorových percepcí. Hume nejenže neprostorovost vášní ze svého postřehu nevyjímá, nýbrž explicitně tvrdí, že jeho tvrzení o tom, že většina toho, co existuje, neexistuje na nějakém místě, vyvolá u běžného publika šok a nesouhlas. ${ }^{58}$ Afekty, vášně a emoce však tvoří právě tak početnou trrídu toho, co zakoušíme, jako vůně, pachy, či barvy, a Hume je v kapitole o nehmotnosti duše, v níž se kvazi-lokalizací zabývá, běžně udává jako př́iklady neprostorových percepcí. ${ }^{59}$ Bylo by tedy nanejvýš podivné, kdyby nás mělo překvapovat tvrzení, že mnoho z toho, co je, by se nikde nenalézalo, kdyby neprostorové obsahy naší mysli nebyly obrazností začleněny do prostoru. V každodenním životě totiž zcela očividně věříme, že se jako osoby všichni nalézáme v prostoru spolu se svými vášněmi. Jinými slovy, přirozeně věříme, že vášně mají také své „kde“ určené pozicí těla. Radujeme se či truchlíme na místě, na kterém se nalézáme, a právě na tomto místě nás vidí radovat se a truchlit i druzí. Podívejme se nyní na celou situaci detailněji.

Z toho, co Hume říká o percepcích, je patrné, že soud vcítění nemůže být úsudkem z vnějšku na nitro. Jestliže se vášně nikde nenacházejí, nemohou být ani uvnitř́, ani venku. Jestliže vášně v běžném životě projikujeme do těla druhé osoby, pak nikoli do těla fyziologického, do jeho nervů, buněk a vnitřností, o nichž mají detailnější povědomí pouze

\footnotetext{
58 Tamt.

59 Tamt., SB 234, 236, 239, 246, 248.
} 
anatomové, nýbrž do těla druhého, které se nám jeví v každodenním životě. Radostný není náš mozek, nýbrž např. naše tvář.

Toto vztažení emocí k tělu dobře naznačuje následující obraz soucitu z třetí knihy Pojednání:

„Předpokládejme, že [troskotající] lod’ se ke mně přiblíží natolik, že mohu zřetelně vnímat hrůzu vkreslenou do vzezření námořníků a cestujících, slyšet jejich zoufalé výkřiky, pozorovat, jak si nejlepší přátelé dávají poslední sbohem, anebo jak se objímají s tím, že si zahynou v náručí. Nikdo nemá tak kruté srdce, aby se dokázal z takové podívané těšit a potlačit pohnutí nejvřelejšího soucitu a sympatie." ${ }^{\text {60 }}$

Hume zajisté nechce říci, že hrůza vkreslená do vzezření je nějak na druhé nanesena, tak jako může být nanesen nátěr na plochu. Strach stejně tak jako chut' nemá podle Huma části, které by šlo přiřazovat k částem prostoru. Krátce řečeno, levá část zoufalého obličeje je levou částí strachu právě tak málo, jako je levá část fíku levou částí jeho chuti. A když Hume tvrdí, že radostné vzezření druhého naplňuje jeho mysl citelnou spokojeností a klidem, ${ }^{61}$ jen stěží může věřit, že radost se nachází někde za vzezřením či, v prŕísném smyslu, $n a$ něm. I vynacházení strachu v prostoru tváře či v těle, jež strach zasahuje, lze však v jistém smyslu charakterizovat jako celé v celku i v libovolné jeho části.

I ostatní okolnosti kvazi-lokalizace vášní mají podle všeho svou analogii v kvazi-lokalizaci smyslových percepcí. Když se druhý raduje, je vztah radosti a úsměvu vztahem dvou vlastností (modů) v rámci téže osoby, a nikoli příčinným vztahem mezi dvěma předměty - vášní a tělem. Pomineme-li faleš a patologické případy, pak úsměv není účinkem, který by jako vyjádření radosti trval, zatímco jeho příčina pominula. Úsměv je znakem přítomného radování, nikoli minulé radosti. Radost a úsměv jsou dva mody, které má osoba naráz.

Psychická stránka druhého je podle našeho výkladu Huma kvazi-lokalizována v prostorovosti stránek tělesných, vášeň je takřríkajíc „vkreslena“ do těla druhého podobně jako je chut' fíku vnesena do jeho tvaru. Pokud by se totiž asociativní vysvětlení vjemu druhého u Huma zastavilo již v prvním kroku, vnímali bychom pouze fyzická těla bez duše a života, která na nepřítomnou duši a psychický život pouze poukazují. Takový popis je však zjevně absurdní. Předložené čtení Huma

\footnotetext{
60 Tamt., III, SB 594.

61 Tamt., II, SB 317.
} 
tedy umožňuje nastínit odpověd’ na otázku, jak by Hume popsal víru doprovázející aktuální prezentaci emocí a vášní druhého v přirozeném postoji pozorovatele..$^{6}$

\section{Závěr}

Z hlediska moderních koncepcí emocí, které odmítají mentalistické hledisko i teorii projekce emocí do druhého subjektu, by bylo možné proti Humovi vznášet mnohé oprávněné námitky. ${ }^{63}$ Hume ale reagoval na teorie vášní 17. století - na Descarta, Malebranche, Hutchesona či Mandevilla. S nimi je třeba jeho filosofii emocí a sympatie srovnávat a př́ležitostně upozorňovat na prvky, které mohou obohatit i současné diskuse. Jedním z nich je Humův důraz na sdílení emocí. Pokusili jsme se poukázat na to, že podle Huma pouhá ideová prezentace vášní neumožňuje intersubjektivní jednání a mezilidský kontakt v běžném smyslu. Za pozornost stojí i konstituce vlastní osoby jakožto vždy nutně libého či nelibého podnětu vlastních a cizích nepřímých vášní či role obecných pravidel jako vodítek pro operace sympatie.

V druhé části jsme chtěli upozornit na málo zohledňovaný rozměr Humova myšlení, totiž že Hume hájí neprostorové uspořádání většiny našich percepcí. Problém možné souvislosti neprostorových a prostorových řádů percepcí řeší zavedením principu fiktivního vztažení neprostorových percepcí k prostorovým percepcím pomocí sekundární asociace na základě soumeznosti (kvazi-lokalizace) a jako příklad volí začlenění percepce chuti do ovoce. Výsledek tohoto vztažení popisuje jako nový způsob začlenění vlastnosti (modu) mezi ostatní vlastnosti (mody) komplexního předmětu.

Snažili jsme se argumentovat pro pozici, že Hume se jen stěží mohl domnívat, že v postoji víry běžného života je svět zabydlený těly, která

62 Je pozoruhodné, že si otázku lokalizace vášní nepoložil žádný z myslitelů Humova širšího okolí, jejichž práce v protikladu $\mathrm{k}$ Humovi hájily přímou a bezprostřední intuitivnost neprostorových emocí druhého na základě jeho tělesných projevů. Tato názornost emocí v gestech, činnostech či výrazech tváře je podle těchto myslitelů přímo zprostředkována vrozenými principy a typově se podobá smyslovému vnímání. Viz H. Home, Elements of Criticism, I., kap. 15, a zejm. T. Reid, Thomas Reid's Lectures on the Fine Arts, The Hague 1973, str. 30-32.

63 Obecnou fenomenologickou kritiku takto zaměřených teorií lze nalézt u Dana Zahaviho, Empathy and Other-Directed Intentionality, in: Topoi, 33, 2014, str. 129-142. 
nás odkazují na nepřítomný emocionální život druhých tak, jako loutky odkazují na loutkaře za kulisami. Pokud je kvazi-lokalizace obecný princip obraznosti, kterému podléhají všechny neprostorové percepce, které jsou jako mody vztaženy ke komplexním předmětům, pak jí musí podléhat i vášně, které jsou tak pojaty jako vlastnosti osob a vepsány do prostoru, který zaujímá tělo osoby. Výrazové tělo tedy podle nás není u Huma jen pouhým nástrojem pro ukazování vášní jako prř́čin tělesných účinků, nýbrž také prostorem, k němuž jsou vášně sekundárně vztaženy. ${ }^{64}$

\section{ZUSAMMENFASSUNG}

Der Beitrag erörtert Humes Theorie der Sympathie (des Mitgefühls) im zweiten Buch seines Traktates über die menschliche Natur mit besonderem Fokus auf die soziale Funktion des Mitgefühls sowie auf die Konstitution unseres eigenen Selbst in den indirekten Affekten. Es wird auf zwei Sachverhalte hingewiesen, die für das Verständnis von Humes Theorie wichtig sind, auch wenn viele Interpreten dazu neigen, sie zu übersehen. Es scheint klar zu sein, dass Hume die Vorstellungen (ideas) der Affekte - im Kontext der Sympathie - nicht als schwächere Kopien oder Schatten der Eindrücke (impressions) der Affekte betrachtet. Damit erschließt sich der Raum für die wichtige Rolle des mitfühlenden, wohlwollenden Teilens der Emotionen. Die notwendige Voraussetzung für ein solches Teilen stellen echte intersubjektive Beziehungen zwischen Personen dar. Des weiteren behauptet Hume nicht, dass Affekte sich einfach durch eine emotionale Ansteckung verbreiten, sondern vielmehr, dass der menschliche Geist eine natürliche Neigung aufweist, die Emotionen anderer Menschen zu übernehmen. Diese Neigung kollidiert allerdings mit anderen Grundsätzen der menschlichen Natur. Der zweite Teil des Beitrags stellt eine Frage, die offensichtlich noch nicht aufgeworfen wurde. Angesichts der räumlich nicht ausgedehnten Natur der Affekte, sind nach Hume Affekte auf körperliche Ausdrucksformen bezogen.

64 Tento článek je výsledkem grantu GA ČR 17-06904S „Meze rozumu ve věku rozumu: spory ve filosofii 18 . století “ realizovaném na Filozofické fakultě Univerzity Hradec Králové. 
The article discusses Hume's theory of sympathy in Book II of his Treatise of Human Nature with special regard to the social function of sympathy as well as to the constitution of one's own self in indirect passions. Two things are pointed out as important for understanding Hume's theory, even though they tend to be overlooked by many commentators. It seems clear that - in the context of sympathy - Hume does not treat ideas of passions as weaker copies or shadows of impressions of passions. This opens up an important role for the sympathetic sharing of emotions, for such sharing is a necessary condition of proper intersubjective relations among persons. Furthermore, Hume does not claim that passions simply spread by emotional infection, but rather that human mind has a natural tendency to take over emotions of other people. However, this tendency clashes with other principles of human nature. The second part of the article poses a question which apparently has not been raised so far. Given the spatially unextended nature of passions, how are passions, according to Hume, related to bodily expressions. 